\title{
Isolation and Characterization of Nucleotide-Binding Site Resistance Gene Homologues in Common Bean (Phaseolus vulgaris)
}

\author{
Luz N. Garzón, Oscar A. Oliveros, Benjamin Rosen, Gustavo A. Ligarreto, \\ Douglas R. Cook, and Matthew W. Blair
}

First, second, fourth, and sixth authors: Facultad de Agronomía, Universidad de Colombia, Bogota, Cra. 30 45-03 Bloque 500, oficina 423; and third and fifth authors: Department of Plant Pathology, University of California-Davis, One Shields Ave., Davis 95616. Accepted for publication 12 October 2012.

\begin{abstract}
Garzón, L. N., Oliveros, O. A., Rosen, B., Ligarreto, G. A., Cook, D. R., and Blair, M. W. 2013. Isolation and characterization of nucleotidebinding site resistance gene homologues in common bean (Phaseolus vulgaris). Phytopathology 103:156-168.

Common bean production is constrained by many fungal, viral, and bacterial pathogens. Thus, the identification of resistance $(R)$ genes is an important focal point of common bean research. The main goal of our study was to identify resistance gene homologues (RGH) in the crop, using degenerate primers designed from conserved sequences in the nucleotide-binding site (NBS) domains of $R$-genes from the model legume Medicago truncatula. Total DNA of the Andean common bean genotype G19833 was used for amplification of over 500 primer combinations.

Sequencing of amplicons showed that 403 cloned fragments had uninterrupted open reading frames and were considered representative of functional RGH genes. The sequences were grouped at two levels of nucleotide identity (90 and 80\%) and representative sequences of each group were used for phylogenetic analyses. The RGH sequence diversity of common bean was divided into TIR and non-TIR families, each with different clusters. The TIR sequences grouped into 14 clades while nonTIR sequences grouped into seven clades. Pairwise comparisons showed purifying selection, although some sequences may have been the result of diversifying selection. Knowledge about RGH genes in common bean can allow the design of molecular markers for pyramiding of resistance genes against various pathogens.
\end{abstract}

Common bean (Phaseolus vulgaris L.) is considered one of the most important sources of food protein especially in developing countries where per capita consumption is higher than $50 \mathrm{~kg}$ in some regions (8). The crop is cultivated in tropical, subtropical, and temperate regions in more than 100 countries around the world, with production of over 23 million tons of dry grain. Various diseases, such as angular leaf spot (caused by Phaeoisariopsis griseola (Sacc.), anthracnose (caused by (Colletotrichum lindemuthianum) (Sacc. \& Magnus) Lams.-Scrib.), rust (caused by (Uromyces appendiculatus) (Pers.: Pers.)), and Ascochyta blight (caused by Phoma exigua) constitute fungal threats to common bean production (61). In addition, common bean is affected by halo blight (Pseudomonas syringae pv. phaseolicola), bacterial blight (Xanthomonas axonopodis pv. phaseoli), and a large number of viral pathogens.

In order to reduce the impact of these diseases, different biological and chemical management strategies have been developed. However, genetic resistance is considered the most useful and advisable in both economic and environmental terms since new resistant varieties are easily adopted by farmers and do not require extraneous inputs (43). The common bean genome is one of the smallest among the legumes (588 to $637 \mathrm{Mbp} / \mathrm{haploid}$ ) and has more than 60 phenotypically described resistance genes $(5,38)$. However, these genes have only been investigated in detail in just

Corresponding author: M. W. Blair; E-mail address: mwbeans@gmail.com

* The $\boldsymbol{e}$-Xtra logo stands for "electronic extra" and indicates that the online version contains two supplementary tables and three supplementary figures. Figures 3 and 4 appear in color online.

http://dx.doi.org/10.1094/PHYTO-07-12-0180-R

(C) 2013 The American Phytopathological Society a few cases, notably for the $I$ gene virus resistance gene (63) and for $\mathrm{Co}-2$ anthracnose resistance gene (21).

Disease resistance against pathogens in plants includes several steps. A first line of defense is dependent upon the perception of pathogen-associated molecular patterns (PAMPs) by pattern recognition receptors. This first event has been denominated PAMPtriggered immunity. Next, defense responses are indirect and direct consequences of interaction between plant resistance proteins encoded by resistance $(R)$ genes and pathogen effectors encoded by avirulence (Avr) genes. If this interaction occurs, the event is denominated "effector triggered immunity" (12). The relationship of $R$ genes and $A v r$ genes is commonly referred to as the "gene-for-gene" model of interaction (18).

To date, over $70 R$-genes have been cloned from various plant species (35). Comparative analysis of these $R$-genes have revealed certain conserved amino acid domains that include nucleotidebinding sites (NBS), leucine-rich repeats (LRR), transmembrane domains, and serine/threonine protein kinases arranged as separate genes or parts of individual genes in different combinations of protein domains (12). In sequenced genomes such as Arabidopsis thaliana it is estimated that $R$-genes are abundant and may represent more than $1 \%$ of the total number of genes (41).

More specifically, the NBS-LRR family of $R$-genes can be grouped into TIR (toll and interleukin-1 receptor) and non-TIR subfamilies, referring to a TIR domain at the N-terminus of the protein that the gene encodes (40). Most of the proteins encoded by non-TIR type $R$-genes have a coiled coil (CC) motif also known as a leucine zipper in the N-terminus region of these proteins (50). The classification of a gene into TIR or non-TIR types can be predicted based on motifs and specific amino acid residues in the proteins (40). Thus, an aspartic acid (D) at the end of Kin-2 and the motifs (LQKKLLSKLL) and RNBS-D (FLHIACFF) are typical of the TIR subfamily. Meanwhile, non- 
TIR proteins have a tryptophan (W) at the end of the Kin-2 motif and the motifs RNBS-A (FDLxAWCCVSQxF) and RNBS-D (CFLYCELPED) inside the NBS domain $(40,51,65)$.

Cloning of $R$-genes has been predominantly through a candidate gene approach either aided by genetic maps or by degenerate primers (1). In the latter case, highly conserved sequences in the P-loop and GLPL motifs of the NBS domain have been used to design degenerate primers which can be used to amplify TIR and non-TIR type $R$-genes in a variety of species. The sequences amplified by these primers are defined as putative resistance genes analogs (RGA) (31), resistance genes candidate (69), or resistance gene homologues (RGH) (9) are all terminologies that refer to similar amplified sequences from $R$-genes; however, we prefer to use the last of these names as it indicates that an ancestral sequence gave rise to orthologous sequences in derived species.

Taking into account that resistance genes have a conserved function even in very different species and remarkable similarity in the NBS domain, a phylogenetic approach to analysis of RGH genes is justified. However, because of their highly duplicated nature and existence as complex and clustered gene families, $R$-genes phylogeny must carefully distinguish orthologous and paralogous sequences. Phylogenetic analyses of this kind of sequences from different plant species strongly suggest that these genes/sequences existed in plant genomes prior to divergence of related species (42).

Many RGAs have been isolated in legume species including common bean, alfalfa (Medicago sativa), cowpea (Vigna unguiculata), chickpea (Cicer arietinum), lentil (Lens culinaris), pea (Pisum sativum), peanut (Arachis hypogaea), and soybean (Glycine max) $(6,9,11,28)$. In the model legume Medicago truncatula, between 400 to 500 NBS-LRR resistance genes have been identified (2) and RGH sequences from this species can be useful for the development of degenerate primers for RGH isolation in other legumes (B. Rosen and D. R. Cook, unpublished data).

In common bean, polymerase chain reaction (PCR)-based $R$-gene analog polymorphism (RGAP) markers were developed from the conserved kinase-1a (GVGKTT) and hydrophobic domains (GLPLAL) of known NBS-LRR type $R$-genes and from expressed sequence tags (EST) databases (46). In the latter study, 32 RGAP markers were mapped in the BAT 93/Jalo EEP558 mapping population, some of which were in the vicinity of known $R$-genes or quantitative trait loci (QTLs) that provided resistance to different diseases such as rust, common bacterial blight, anthracnose, bacterial brown spot, web blight, white mold, angular leaf spot, halo bacterial blight, and Fusarium wilt (43).

Other research by Lopéz et al. (37) isolated and evaluated common bean RGA amplicons derived from NBS and TIR domains. In that study, eight classes of RGAs were mapped in genomic regions containing QTL associated with resistance to anthracnose, angular leaf spot, and Bean golden yellow mosaic virus (BGYMV).

In a more recent study, the gene expression of some RGA genes in common bean was studied with a transcriptomic approach (16). That research used a data mining approach with 176,011 sequences from next generation or EST sequencing and a database of $50 R$-genes. A total of 365 unique sequences were identified and named PvRGLs (resistance gene loci of Phaseolus vulgaris). The expression of 24 selected PvRGLs was confirmed through the reverse transcription-PCR method. The large number of colocalization observed between RGAs and QTLs linked to resistance in other species (39) suggests that the further cloning and mapping of RGA sequences will be useful in common bean.

The objective of this study was to identify NBS-LRR diversity in common bean using primers derived from Medicago RGH sequences, which were amplified in the Andean genotype G19833 that has been used for a shotgun-sequencing and genome annotation project. Work in common bean is desirable to make comparative studies with other species from the genus Phaseolus or from the legume family (24). A considerable number of degenerate primers (over 500) were evaluated for this study, making it the most comprehensive study to date in putative sequences that encode for TIR and non-TIR proteins in common bean. A phylogenetic analysis and characterization of these sequences is carried out and discussed.

\section{MATERIALS AND METHODS}

Plant materials and DNA extraction. This study was carried out with the genotype G19833, which is a Peruvian landrace from the Andean gene pool with large yellow with red mottled seed and resistance to various fungal pathogens (37), that has been chosen for whole genome sequencing and annotation for the common bean genome. G19833 is a parent of a central mapping population that has been used to place simple sequence repeat- and single nucleotide polymorphism-based markers across the bean genome $(7,19,20)$. In addition to having ESTs from cDNA libraries (55), a G19833 BAC library has been made (Blair and Muñoz, unpublished data) which was useful for physical map construction (60) and for BAC end sequencing in the whole-genome sequencing project. Genomic DNA from young leaves of this genotype was extracted using the cetyl-trimethyl-ammonium bromide method as described by Dellaporta et al. (13) and used by Vallejos et al. (64) for common bean DNA purification.

RGH sequences amplification. Amplification of candidate RGAs was carried out using degenerate primers designed at the University of California-Davis, based on conserved sequences in the P-loop and GLPL motifs of the NBS domain of RGH sequences based on confirmed and well-characterized $R$-genes from $M$. truncatula (S. Steiner, personal communication).

A total of 49 degenerate primers were used: 24 designed from conserved TIR type sequences ( 8 forward and 16 reverse) and 25 primers derived from conserved non-TIR type sequences ( 9 forward and 16 reverse). In total, $40.8 \%$ of the primers were degenerate by a factor of 192 -fold, while only $22.4 \%$ were 96 -fold degenerate. The remaining $36.8 \%$ were $72-$, 128-, 256-, 288-, and 512-fold degenerate (Supplementary Table 1). All 544 possible primer combinations between the forward and reverse primers were used for PCR (Table 1). Each PCR was carried out in a final volume of $20 \mu \mathrm{l}$ using an ExTaq enzyme kit for amplification (Takara Bio Inc., Japan).

PCR mix contained $40 \mathrm{ng}$ of genomic template DNA, $0.15 \mathrm{U}$ of ExTaq polymerase $(5 \mathrm{U} / \mu \mathrm{l}), 1.25 \times$ of $10 \times$ ExTaq buffer $(20 \mathrm{mM}$ $\mathrm{Mg} 2+$ plus), $0.2 \mathrm{mM}$ of ExTaq dNTPs, and $0.10 \mu \mathrm{M}$ of each primer combination. Amplification was carried out in a Tetrad 2 DNA Engine Thermoycler (MJ Research, Bio-Rad Laboratories), programmed for an initial cycle of $95^{\circ} \mathrm{C}$ for $3 \mathrm{~min}$ and $50^{\circ} \mathrm{C}$ for $3 \mathrm{~min}, 72^{\circ} \mathrm{C}$ for $3 \mathrm{~min}$, followed by 29 cycles of $94^{\circ} \mathrm{C}$ for $1 \mathrm{~min}$,

TABLE 1. Primer combinations used to amplify bean resistance gene homologous genes

\begin{tabular}{|c|c|c|c|c|c|}
\hline Type of primer & Primer direction & Primer series & Total number of primers & Primer combinations & $\begin{array}{c}\text { Total number of primer } \\
\text { combinations }\end{array}$ \\
\hline \multirow[t]{2}{*}{ TIR } & Reverse & TIR-R & 16 & TIR-F + TIR-R & 128 \\
\hline & Forward & TIR-F & 8 & TIR-F + non-TIR-R & 128 \\
\hline \multirow[t]{2}{*}{ non-TIR } & Reverse & non-TIR-R & 16 & non-TIR-F + TIR-R & 144 \\
\hline & Forward & non-TIR-F & 9 & non-TIR-F + non-TIR-R & 144 \\
\hline Total primer evaluated & & & & & 544 \\
\hline
\end{tabular}


$50^{\circ} \mathrm{C}$ for $1 \mathrm{~min}, 72^{\circ} \mathrm{C}$ for $1 \mathrm{~min}$, and a final extension step of $72^{\circ} \mathrm{C}$ for $5 \mathrm{~min}$. Amplicons were separated on $1.0 \%$ agarose gels run in Tris-borate-EDTA buffer and visualized by ethidium bromide staining.

Cloning and sequencing of RGH amplicons. PCR products between 400 and $700 \mathrm{bp}$ were selected for cloning which was carried out with the TOPO TA Cloning Kit (Invitrogen). Ligation reactions were carried out by mixing $2 \mu \mathrm{l}$ of PCR product, $0.5 \mu \mathrm{l}$ of the pCR 4-TOPO cloning vector, and $0.5 \mu \mathrm{l}$ of a salt solution. These reagents were incubated for $30 \mathrm{~min}$ at room temperature. TOPO10 competent cells of Escherichia coli (Invitrogen) were transformed using $2 \mu \mathrm{l}$ of the ligation product and $37.5 \mu \mathrm{l}$ of CBB80 medium. After $30 \mathrm{~min}$ on ice, cell transformation was carried out by heat shock at $42^{\circ} \mathrm{C}$ for $30 \mathrm{~s}$ and subsequently chilled on ice. The transformation mix was added to $250 \mu$ of SOC medium and transferred to a shaker incubator for $1 \mathrm{~h}$ at 225 revolutions per minute. Finally, $250 \mu$ of new SOC medium was added and the transformed cells were plated onto $200 \mu \mathrm{l}$ of Luria broth agar containing $50 \mathrm{mg}$ of kanamycin per liter. The plates were then incubated at $37^{\circ} \mathrm{C}$ for $24 \mathrm{~h}$ before colony picking was carried out with a Q-Bot (Genetix System, Inc.) robot.

A total of 192 colonies were picked for each primer pair. These were maintained in 384-well plates in a freezing-medium containing kanamycin $(50 \mu \mathrm{g} / \mathrm{ml})$ incubated at $37^{\circ} \mathrm{C}$ for $24 \mathrm{~h}$ and then frozen at $-80^{\circ} \mathrm{C}$. Plasmid DNA from 12 clones per primer pair were extracted using a Wizard SV-96 DNA Purification System DNA and sent for sequencing. The obtained sequences revealed the primer combinations with one or more positive clones for $\mathrm{RGH}$ fragments and these were chosen for deeper sequencing of 24 additional clones. All DNA sequencing was performed at the College of Agricultural \& Environmental Sciences Genomics Facility (University California-Davis), on an automated ABI 3730 XL capillary sequencer (Applied Biosystems Inc., Foster City, CA). The M13 forward primer was used in all unidirectional sequencing reactions. Sequences were trimmed with Seq Trim so that only insert sequences were analyzed.

Phylogenetic analysis. Hidden-Markov model analyses were conducted with BioJava to identify vector contamination versus $\mathrm{RGH}$ sequences. Trimmed sequences were compared with a database of $M$. truncatula $\mathrm{RGH}$ and $R$-genes sequences from the National Center of Genomics Resources (NCGR) in order to identify $R$-gene homologues and to classify them into TIR or non-TIR subsets. The sequence analysis was performed using the Blastx algorithm and a cut off threshold of $\mathrm{e}^{-10}$. Finally, the correct reading frame of the sequence and any stop codons indicating an incomplete open reading frame (ORF) were determined and then the gene sequence was trimmed to a full set of codons.

$R$-gene sequences were then aligned with MAFFT software with default options (http://mafft.cbrc.jp/alignment/software) (Supplementary Figures 1 and 2). Subsequent visual adjustment and editing was carried out in Jalview (http://www.jalview.org). The Phylip/Phylip4 sequence formats were obtained using Readseq (http://www.ebi.ac.uk/cgi-bin/readseq.cgi). Phylogenetic analyses were conducted with the maximum likelihood (ML) method specifically using the RAxML (randomized accelerated maximum likelihood) protocol. Computations were performed on the computer cluster of the Cyber-Infrastructure for Phylogenetic Research (CIPRES) project. The parameters were maintained at default settings with analyses conducted at nucleotide and amino acid levels. The program Fig Tree was used to import and draw trees from Newick format files (http://tree.bio.ed.ac.uk/software/ figtree).

Phylogenetic analyses were carried out in two phases: first, considering only RGH sequences for common bean obtained in this work; and second, considering RGH sequences previously reported for common bean or other legume and plant species. In order to include all of the RGH sequences published for Phaseolus vulgaris, an exhaustive search was conducted through the GenBank database of the National Center for Biotechnology Information (NCBI, Bethesda, MD). The terms used were as follows: NBSLRR disease resistance-like protein, TIR-like putative resistance protein, putative resistance protein (RGA) gene, NBS-LRR like putative resistance protein, resistance-like protein, NBS-LRR type putative disease resistance protein, resistance protein analog, and disease resistance protein-like gene.

Cloned $R$-genes from other legumes corresponding to NBSLRR type RGA sequences reported by Yaish et al. (66) in lentil and in M. truncatula and Palomino et al. (48) in faba bean (Vicia faba) and chickpea (Cicer arietinum) were also included. Sequences related to fully characterized resistance proteins from nonlegume plants species were included in a further analysis. These involved the cloned genes RPS4 (AJ243468), RPP1 (AF098962), RPM1 (X87851), RPP13 (AF209730), and RPP8 (AF089711) from Arabidopsis thaliana; L6 (LUU27081) from flax (Linum utilissimum L.); $N$ (NGU15605) from tobacco (Nicotiana tabacum L.); I2 (AF004878) from tomato (Solanum lycopersicon L.); Xal (AB002266) from rice (Oryza sativa L.); and Rpl (AF107293) from maize (Zea mays L.).

The RPS2 sequence (EF560565.1) from A. thaliana (ecotype Ws-2) was used to root the phylogenetic tree made with common bean RGH sequences obtained in this work, while a mammalian sequence, APAF-1, was chosen to root the global phylogenetic tree.

Pairwise sequence alignments from representative sequences within the same family were made in order to evaluate the synonymous (Ks) and nonsynonymous (Ka) amino acid substitutions and to calculate the $\mathrm{Ks} / \mathrm{Ka}$ value $\omega$ using the software program Codelm that is part of the PAML software package (http://abacus. gene.ucl.ac.uk/software/paml.html). In order to confirm the $\omega$ values, the same ratio was calculated using another software package, DNAsp (http://www.ub.edu/dnasp/) (33). Additionally, the MEME (Multiple EM for Motif Elicitation, http://meme. sdsc.edu/meme/intro.html) from Bailey and Gribskov (4) was used to discover conserved NBS motifs in amino acid sequences from TIR and non-TIR families. Motif probabilities were based on residues appearing at each possible position and were displayed in a graphic manner as "sequence LOGOS."

\section{RESULTS}

Amplification of common bean RGH sequences. A total of 544 primer combinations based on 49 degenerate RGH oligonucleotide sequences were used to amplify common bean RGH sequences for this study. The amplifications showed band sizes between 50 and 3,000 bp in length. However, since the genomic region between the P-loop and GPLP of NBS-LRR type $R$-genes in $M$. truncatula is between 400 and $700 \mathrm{bp}$ in length, we only cloned this approximate size for sequencing of RGH fragments. In order to ensure the identification of the highest numbers of putative RGHs, a two-step strategy was used. In the first step we sequenced 12 colonies from each primer combination. In the second step after this initial sequencing, the primer combinations that amplified one or more confirmed RGH sequences were chosen for deeper sequencing of an additional 24 colonies. Overall in the initial screening, 228 primer combinations (42\%) produced amplicons with RGH sequences based on sequencing of a total of 2,736 clones ( 12 clones per primer combination). BlastX of the trimmed sequences against the NCGR database of $M$. truncatula $R$-genes was used to identify resistance gene homologues and to classify them into TIR and non-TIR families. This analysis allowed us to identify 155 sequences with full conserved motifs that encoded NBS type proteins from $R$-genes. This was equivalent to $5.7 \%$ of the total sequenced fragments. The positive sequences were obtained with 73 different primer combinations, corresponding to $13.4 \%$ of the 544 primer combinations evaluated. 
The negative clones had mostly partial motifs, non-RGH sequences or had sequences with homology to transposons and retrotransposons. In deeper sequencing of the positive primer combinations, a total of 4,486 clones were sequenced of which 1,317 failed to sequence well and the majority of the remaining clones were eliminated because they showed homology with transposons and retrotransposons in blastn searches. The analysis of the remaining sequences showed 403 clones (9.0\%) with homology to NBS-LRR domains of known $R$-genes or RGH sequences cloned from $M$. truncatula. The corresponding 403 NBS-containing amino acid sequences were screened for motifs characteristic of RGH proteins and the sequences were then classified as TIR or non-TIR type putative $R$-genes. Nearly half (47.9\%) of the NBS sequences were of the TIR class corresponding to 193 sequences, with slightly more (52.1\%) sequences being of the non-TIR class, corresponding to 210 sequences (Table 2).

ORF prediction was used to determine the correct codons of each putative $R$-gene and possible stop codons. A total of 158 TIR and 153 non-TIR sequences showed uninterrupted ORFs and were considered true RGH genes. The remaining sequences were not included in the phylogenetic analysis because they contained early stop codons and/or frame-shift mutations and were considered to be pseudogenes or PCR errors. The average size of the trimmed and selected RGH sequences was $462 \mathrm{nt}$ (with a range between 100 and $517 \mathrm{nt}$ ). The shortest sequences from 100 to $370 \mathrm{nt}$ were eliminated and as a result the remaining sequences varied from 406 to $517 \mathrm{nt}$. Redundant sequences were also eliminated using a nucleotide identity threshold value of $99 \%$, where 56 TIR type sequences and 57 non-TIR type sequences were discarded.

Success rate of various primer combinations. A comparison of the sequence results and the primer combination used showed that the class of RGH genes identified did not exhibit an association with the primer combinations used. For example, primer combinations TIR+TIR, which are primers designed only from TIR sequences, amplified TIR type RGH but also non-TIR type RGH sequences. Likewise, non-TIR and non-TIR primer combinations detected both TIR type and non-TIR type RGH genes. The number of RGH sequences identified with the 73 primer combinations ranged from 1 to 15 , with an average of 5 amplicons per primer combination (Table 3 ).

Most of the RGH sequences identified were amplified by 34 non-TIR+non-TIR primer pairs (182 sequences, corresponding to $46 \%$ ), followed by 24 TIR+non-TIR primer pairs (141 sequences, corresponding to $32 \%$ ). The other combination classes of TIR+TIR and non-TIR+TIR produced almost the same amount of RGH sequences (12 and 9.5\%, respectively). Some primer combination amplified both TIR and non-TIR sequences together. However, the non-TIR+TIR combination did not show this pattern. It was notable that TIR+TIR combination produced a mix of TIR and non-TIR sequences. In summary, the percentages of RGH sequences generated by each primer combination were variable, although the number of primers and their combinations were all very similar (16 reverse primers for TIR and non-TIR, 8 forward primers for TIR, and 9 forward primers for non-TIR). Finally, the primer combinations produced variable numbers of appropriately sized fragments ranging from 39 to 69 for each.

Phylogeny of newly discovered common bean RGH sequences. Phylogenetic analyses were performed using the common bean RGH sequences, considering only the common segments from the NBS regions found after trimming the primer sequences (P-loop and GLPL). Multiple alignments allowed us to group those sequences sharing $90 \%$ nucleotide identity. We selected this identity level because of our goal of identifying the maximum number of paralogous genes but we also followed the recommendations of Quirin et al. (53) to set gene family identity for RGH genes at $80 \%$ nucleotide identity. The number of sequences per group ranged from 1 to 21 for TIR sequences and from 1 to 25 for non-TIR sequences at $90 \%$ identity with higher limits at the $80 \%$ level. For each group, one sequence with the highest similarity values with the other sequences was chosen as a representative sequence to use in the phylogenetic analysis. After consolidating the data set to only the representative RGH sequences at the $90 \%$ identity level, 53 sequences were included in the phylogenetic tree (Fig. 1), 27 of which were TIR type and 26 of which were non-TIR type. These sequences were uploaded to GenBank with the accession numbers JQ313582 to JQ313634. At the $80 \%$ level, 17 TIR and 12 non-TIR clades or gene families were identified by phylogenetic analysis (Supplementary Figure 3 ). Because the phylogenetic trees obtained with nucleotide sequences and with deduced amino acid sequences had similar topologies, only the amino acid results are shown. Protein analysis was chosen because codon degeneracy can produce the same amino acid from different codons. Therefore, the pairwise comparison at the protein level is more reliable and the homology between amino acid sequences was generally higher than that of nucleotide sequences.

In the phylogenetical analysis at $90 \%$ identity, three sequences (JQ313603, JQ313604, and JQ313605) were eliminated because of their distance from the main branches of the tree. After this, three main clusters were evident for each family of RGH sequences (TIR and non-TIR). These clusters grouped a total of 14 clades of TIR sequences defined as clade 1 to clade 14 and 7

TABLE 2. Resistance gene homologues (RGH) and unique sequences found in common bean with RGH primer amplification along with the amount of genes and pseudogenes distinguished among unique sequences

\begin{tabular}{|c|c|c|c|c|c|c|}
\hline \multirow[b]{2}{*}{$R$-gene class } & \multirow[b]{2}{*}{ ORF containing } & \multirow[b]{2}{*}{ non-ORF } & \multirow[b]{2}{*}{ Total sequences } & \multicolumn{3}{|c|}{ Unique sequences } \\
\hline & & & & ORF containing & non-ORF & Total \\
\hline TIR & 158 & 35 & 193 & 105 & 33 & 138 \\
\hline non-TIR & 153 & 57 & 210 & 116 & 48 & 164 \\
\hline
\end{tabular}

TABLE 3. Number of resistance gene homologous (RGH) sequences amplified by different types of primer combinations

\begin{tabular}{|c|c|c|c|c|c|c|c|c|c|}
\hline \multirow{2}{*}{$\begin{array}{l}\text { Type of primer } \\
\text { combination } \\
\text { (forward + reverse) }\end{array}$} & \multirow{2}{*}{$\begin{array}{l}\text { Number of primer } \\
\text { combinations } \\
\text { evaluated }\end{array}$} & \multirow{2}{*}{$\begin{array}{l}\text { Number of primer } \\
\text { combinations that amplified } \\
400 \text { - to } 700 \text {-bp fragments }\end{array}$} & \multicolumn{5}{|c|}{$\begin{array}{l}\text { Number of primer combinations } \\
\text { that amplified RGH sequences }\end{array}$} & \multirow{2}{*}{$\begin{array}{l}\text { Final } \\
\text { number } \\
\text { of RGH }\end{array}$} & \multirow[b]{2}{*}{$\%$} \\
\hline & & & non-TIR & $\begin{array}{l}\text { TIR and } \\
\text { non-TIR }\end{array}$ & TIR & Total & $(\%)$ & & \\
\hline TIR + non-TIR & 128 & 69 & 6 & 4 & 14 & 24 & 32.0 & 141 & 35 \\
\hline non-TIR + TIR & 144 & 39 & 2 & 0 & 5 & 7 & 9.5 & 36 & 9 \\
\hline non-TIR + non-TIR & 144 & 69 & 6 & 4 & 24 & 34 & 46.0 & 182 & 45 \\
\hline
\end{tabular}


clades of non-TIR sequences defined as clade 15 to clade 21 . Ten of these clades, 7 for TIR genes and 3 for non-TIR genes, had only a single representative sequence each, showing that they were unique clades and that a diversity of RGH sequences exists in common bean. The phylogenetic tree showed TIR and non-TIR subfamilies as two major branches with high bootstrap values of 94 and $86 \%$, respectively. The NBS domain of RPS2 from $A$. thaliana was a useful outgroup for anchoring the common bean
TIR and non-TIR groups. It was noted that Phaseolus vulgaris sequences were more similar amongst each other than with the RPS2 gene sequence.

Apart from the phylogenetic analysis, differentiation between TIR and non-TIR sequences was also evident in the Kin- 2 and Kin-3 conserved motifs that are part of the NBS domain. The deduced amino acid sequence differences between 105 TIR-NBS and 116 non-TIR-NBS proteins are shown in Table 2. All non-



Fig. 1. Phylogenetic tree of Phaseolus vulgaris resistance gene homologue (RGH) sequences clustered at 90\% identity and constructed with RAxML and using RPS2 from Arabidopsis thaliana to root the tree. 
TIR amino acid sequences had a characteristic tryptophan residue (W); while TIR homologous sequences were more variable with aspartic acid (D), asparagine $(\mathrm{N})$, serine $(\mathrm{S})$, proline $(\mathrm{P})$, or threonine $(\mathrm{T})$ residues at the final amino acid position of the Kin2 motif. Relative entropy of these motifs is shown in the logos found in Figure 2. Apart from the Kinase motifs, the deduced TIR-NBS proteins exhibited a highly conservative sequence of SLEL[FL]SWHAF at the C-terminus (amino acids 159 to 168). Meanwhile, most of the non-TIR-NBS sequences exhibited the consensus sequence WVC[VI]SD[DH]F at the N-terminus (amino acids 32 to 39). Presence of these sequences is characteristic of NBS-LRR disease resistance proteins. The highest-scoring hits using the motifs present in our sequences were with RGAs from Phaseolus vulgaris and Helianthus annuus (data not shown).

Phylogenetic analysis with other legume RGH and nonlegume $\boldsymbol{R}$-genes. A total of 67 common bean sequences with similarity to NBS-LRR genes were found in GenBank and were included in a second phylogenetic analysis. These were classified into 27 Andean sequences from the genotypes G19833, JaloEEP558, and Sprite; and 22 Mesoamerican sequences from the genotypes BAT93, DOR364, and Negro Jamapa. A further nine sequences were found for Olathe and Sierra, also Mesoamerican beans but of race Durango. Seven sequences reported as RGA markers from a Mesoamerican genotype (27) were also included and two more common bean sequences (AF098970.1 and AF098971.1) without genotype information were incorporated. A complete description of all of these sequences is found in Table 4.

Sequences from the Andean genotype JaloEEP558 (EU856787.1, EU856786.1, EU856785.1, EU856784.1, EU856783.1, and EU856782.1) and from the Mesoamerican genotype BAT93 (EU856792.1, EU856791.1, EU856790.1, EU856789.1, and
EU856788.1) were not included in this analysis because they were cataloged as resistance-like pseudogenes.

Therefore, a total of 49 sequences obtained from GenBank were considered common bean RGH genes comparable to the new sequences we had obtained. For species comparisons, 123 RGA sequences from other legumes such as chickpea (25 sequences), faba bean (44 sequences), lentil (23 sequences), and $M$. truncatula (31 sequences) were also included along with resistance proteins from Arabidopsis (RPS4, RPP1, RPM1, RPP13, $R P P 8)$, corn $(R P 1)$, flax $(L 6)$, rice $(X a-1)$, tobacco $(N)$, and tomato (I2).

The sequences described above were grouped into two new phylogenetic trees for TIR and non-TIR clades (Figs. 3 and 4), considering only the NBS region without the P-loop and GLPL regions and using the nucleotide identity threshold of $90 \%$. Based on this criterion only 12 of the 67 previously reported RGAs from common bean were included: EU856770.1, EU856776.1, AF072168.1, AF143553.1, AF363798.1, AF363804.1, AF478172.1, AF478173.1, AF478174.1, AF478175.1, AF478176.1, and AY237123.1. Similarly, only 43 of the legume sequences were used: 6 from chickpea, 5 from faba bean, 12 from lentil, and 20 from M. truncatula (Supplementary Table 2). Therefore, the new phylogenetic trees were constructed with 113 sequences in total including the $50 \mathrm{RGH}$ sequences obtained in this work, 10 resistance genes from other species and APAF1 as an outgroup sequence to root the tree.

Nucleotide sequences obtained from GenBank and RGH sequences isolated in this work had an average length of $480 \mathrm{bp}$ encoding 155 amino acids. Although the sequence AF478171 was over $500 \mathrm{bp}$ it showed less than $90 \%$ nucleotide identity to other sequences and was eliminated from the phylogenetic analysis.

\section{NBS gene type Motif Kin-2}

\section{Motif Kin-3}



Fig. 2. Amino acid sequence logos. Relative entropy of conserved positions for Kin-2 and Kin-3 motifs across 105 TIR and 116 non-TIR nucleotide-binding sites (NBS) leucine-rich repeat sequences is shown. Numbers below sequence logo indicate residue positions. 
The RGHs obtained from common bean formed defined clades and these RGHs were not clustered with the NBS domain of other plant species such as rice, flax, corn, tobacco, and tomato. Common bean sequences were clustered with sequences from the Phaseolus vulgaris sequences collected in genebank regardless of the genotype. Other legume RGH sequences, were included along with common bean RGH sequences in some clades, most being from M. truncatula. Lentil, chickpea, and faba bean RGHs were largely separate except in a few cases where they were clustered with common bean RGH sequences.

TABLE 4. Description of resistance genes from Phaseolus vulgaris included in the phylogenetic analysis, with GenBank nucleotide and their protein identities (ID)

\begin{tabular}{|c|c|c|c|c|c|}
\hline Genotype & ID nucleotide & ID protein & Gene pool & Description & Reference \\
\hline G19833 & AF084026.1 & AAC33296.1 & A & NBS type putative resistance protein gene & $(37)$ \\
\hline G19833 & AF478170.1 & AAO33123.1 & A & NBS-like putative resistance protein (RGA2) gene & (37) \\
\hline G19833 & AF478171.1 & AAO33124.1 & A & NBS-like putative resistance protein (RGA3) gene & (37) \\
\hline G19833 & AF478173.1 & AAO33126.1 & A & NBS-like putative resistance protein (RGA5) gene & (37) \\
\hline G19833 & AF478175.1 & AAO33128.1 & A & NBS-like putative resistance protein (RGA7) gene & (37) \\
\hline G19833 & AF478176.1 & AAO33129.1 & A & NBS-like putative resistance protein (RGA8) gene & (37) \\
\hline JaloEEP558 & AF072168.1 & AAC26763.1 & A & Clone PRLJ1 putative resistance protein (RGA) gene & (23) \\
\hline JaloEEP558 & AF143551.1 & AAF81615.1 & A & Clone PRLJ4 resistance protein analog gene & na \\
\hline JaloEEP558 & AF143556.1 & AAF81617.1 & A & Clone PRLJ2 resistance protein analog gene & na \\
\hline JaloEEP558 & AF143557.1 & AAF81618.1 & A & Clone PRLJ3 resistance protein analog gene & na \\
\hline JaloEEP558 & AF306501.1 & AAK61317.1 & A & NBS-LRR resistance-like protein $\mathrm{J} 71$ (J71) mRNA & (16) \\
\hline JaloEEP558 & AF306502.1 & AAK61318.1 & A & NBS-LRR resistance-like protein J78 (J78) mRNA & (16) \\
\hline JaloEEP558 & AF306505.1 & AAK61321.1 & A & NBS-LRR resistance-like protein J71 (J71) gene & (16) \\
\hline JaloEEP558 & AF306506.1 & AAK61322.1 & A & NBS-LRR resistance-like protein $\mathrm{J} 78(\mathrm{~J} 78)$ gene & (16) \\
\hline JaloEEP558 & AY237123.1 & AAO62728.1 & A & NBS-LRR resistance-like protein (JA1tr) gene isoforms & (17) \\
\hline JaloEEP558 & EU856778.1 & ACJ22819.1 & A & NBS-LRR type putative disease resistance protein CNL-J1 gene & (22) \\
\hline JaloEEP558 & EU856779.1 & ACJ22820.1 & A & NBS-LRR type putative disease resistance protein CNL-J3 gene & (22) \\
\hline JaloEEP558 & EU856780.1 & ACJ22821.1 & A & NBS-LRR type putative disease resistance protein CNL-J9 gene & $(22)$ \\
\hline JaloEEP558 & EU856781.1 & ACJ22822.1 & A & NBS-LRR type putative disease resistance protein CNL-J5 gene & (22) \\
\hline Sprite & DQ002468.1 & ABA00702.1 & A & Disease resistance protein gene & $(63)$ \\
\hline Sprite & DQ002469.1 & NA & A & Disease resistance protein-like gene & $(63)$ \\
\hline Sprite & DQ002470.1 & NA & A & Disease resistance protein-like gene & $(63)$ \\
\hline Sprite & DQ002471.1 & NA & A & Disease resistance protein-like gene & $(63)$ \\
\hline Sprite & DQ002472.1 & NA & A & Disease resistance protein-like gene & (63) \\
\hline Sprite & DQ002473.1 & NA & A & Disease resistance protein-like gene & $(63)$ \\
\hline Sprite & DQ002474.1 & NA & A & Disease resistance protein-like gene & $(63)$ \\
\hline Sprite & DQ002475.1 & NA & A & Disease resistance protein-like gene & $(63)$ \\
\hline BAT93 & AF072167.1 & AAC26762.1 & MA & PRLB1 putative resistance protein (RGA) gene & $(23)$ \\
\hline BAT93 & AF306499.1 & AAK61315.1 & MA & NBS-LRR resistance-like protein B8 (B8) mRNA & (16) \\
\hline BAT93 & AF306500.1 & AAK61316.1 & MA & NBS-LRR resistance-like protein B11 (B11) mRNA & (16) \\
\hline BAT93 & AF306503.1 & AAK61319.1 & MA & NBS-LRR resistance-like protein $\mathrm{B} 8(\mathrm{~B} 8)$ gene & (16) \\
\hline BAT93 & AF306504.1 & AAK61320.1 & MA & NBS-LRR resistance-like protein B11 (B11) gene & (16) \\
\hline BAT93 & EU856769.1 & ACJ22810.1 & MA & NBS-LRR type putative disease resistance protein CNL-B7 gene & $(22)$ \\
\hline BAT93 & EU856770.1 & ACJ22811.1 & MA & NBS-LRR type putative disease resistance protein CNL-B8 gene & $(22)$ \\
\hline BAT93 & EU856771.1 & ACJ22812.1 & MA & NBS-LRR type putative disease resistance protein CNL-B 11 gene & $(22)$ \\
\hline BAT93 & EU856772.1 & ACJ22813.1 & MA & NBS-LRR type putative disease resistance protein CNL-B16 gene & $(22)$ \\
\hline BAT93 & EU856773.1 & ACJ22814.1 & MA & NBS-LRR type putative disease resistance protein CNL-B17 gene & $(22)$ \\
\hline BAT93 & EU856774.1 & ACJ22815.1 & MA & NBS-LRR type putative disease resistance protein CNL-B18 gene & $(22)$ \\
\hline BAT93 & EU856775.1 & ACJ22816.1 & MA & NBS-LRR type putative disease resistance protein CNL-B19 gene & $(22)$ \\
\hline BAT93 & EU856776.1 & ACJ22817.1 & MA & NBS-LRR type putative disease resistance protein CNL-B22 gene & $(22)$ \\
\hline BAT93 & EU856777.1 & ACJ22818.1 & MA & NBS-LRR type putative disease resistance protein CNL-B23 gene & (22) \\
\hline BAT93 & EU856768.1 & ACJ22809.1 & MA & NBS-LRR type putative disease resistance protein CNL-B3 gene & $(22)$ \\
\hline BAT93 & AF143553.1 & AAF81616.1 & MA & Clone PRLB5 resistance protein analog gene & na \\
\hline BAT93 & AF143555.1 & NA & MA & Clone PRLB2 resistance protein analog-like gene & na \\
\hline BAT93 & AF143554.1 & NA & MA & Resistance protein analog-like gene & na \\
\hline BAT93 & AF143552.1 & NA & MA & Clone PRLB4 resistance protein analog-like gene & na \\
\hline DOR364 & AF478174.1 & AAO33127.1 & MA & NBS-like putative resistance protein (RGA6) gene & $(37)$ \\
\hline DOR364 & AF478172.1 & AAO33125.1 & MA & NBS-like putative resistance protein (RGA4) gene & (37) \\
\hline Jamapa & DQ002476.1 & NA & MA & Disease resistance protein-like gene & $(63)$ \\
\hline Olathe & AF363801.1 & AAK50046.1 & NA & Disease resistance protein OB3 (RGA) gene & $(57)$ \\
\hline Olathe & AF363802.1 & AAK50047.1 & NA & Disease resistance protein OB5 (RGA) gene & $(57)$ \\
\hline Olathe & AF363803.1 & AAK50048.1 & NA & Disease resistance protein OB8 (RGA) gene & $(57)$ \\
\hline Olathe & AF363804.1 & AAK50049.1 & NA & Disease resistance protein OB9 (RGA) gene & $(57)$ \\
\hline Sierra & AF363796.1 & AAK50041.1 & NA & Disease resistance protein SB1 (RGA) gene & $(57)$ \\
\hline Sierra & AF363797.1 & AAK50042.1 & NA & Disease resistance protein SB3 (RGA) gene & $(57)$ \\
\hline Sierra & AF363798.1 & AAK50043.1 & NA & Disease resistance protein SB4 (RGA) gene & $(57)$ \\
\hline Sierra & AF363799.1 & AAK50044.1 & NA & Disease resistance protein SB5 (RGA) gene & $(57)$ \\
\hline Sierra & AF363800.1 & AAK50045.1 & NA & Disease resistance protein SB8 (RGA) gene & $(57)$ \\
\hline NA & AF098970.1 & AAD13036.1 & NA & NBS-LRR-like protein cD7 (CO-2) mRNA & (11) \\
\hline NA & AF098971.1 & AAD 13037.1 & NA & NBS-LRR-like protein cD8 (CO-2) mRNA & (11) \\
\hline NA & HM126538.1 & NA & NA & RGA marker RNF330 genomic sequence & $(27)$ \\
\hline NA & HM126539.1 & NA & NA & RGA marker RNF356 genomic sequence & $(27)$ \\
\hline NA & HM126540.1 & NA & NA & RGA marker RNF475 genomic sequence & (27) \\
\hline NA & HM126541.1 & NA & NA & RGA marker RRF380 genomic sequence & (27) \\
\hline NA & HM126542.1 & NA & NA & RGA marker RRF410 genomic sequence & $(27)$ \\
\hline NA & HM126543.1 & NA & NA & RGA marker RKF310 genomic sequence & (27) \\
\hline NA & HM126544.1 & NA & NA & RGA marker RKR240 genomic sequence & $(27)$ \\
\hline
\end{tabular}




\section{DISCUSSION}

A significant accomplishment of the present study was to obtain a large number of RGH sequences and to evaluate their similarity and relationships with each other or with other $R$-gene sequences from common bean. A total of 311 sequences were classified as successful RGH gene fragments based on having an uninterrupted ORF with high identity to $R$-genes from $M$. truncatula and containing conserved motifs such as Kin-2 or Kin-3 typical of NBS-LRR type genes. Other studies have had success at isolating bean RGH sequences with degenerate primers (37); however, in our study we used many primer pairs and size selection to target NBS-containing genes and isolate a fuller range of RGH genes.

In this study, a total of 73 primer combinations were efficient for amplifying RGH sequences from common bean. Of these, 13 amplified exclusively TIR sequences, 13 only non-TIR sequences and the remaining 48 primer combinations amplified TIR and non-TIR sequences. Therefore, cross-reaction of TIR and nonTIR primers producing both TIR and non-TIR genes was observed. This means that the family or the type of RGH sequence detected was largely independent of the primer combination used. Furthermore, the amplification of TIR or non-TIR sequences appear to be more related to the plant species genome than to primer specificity, and many primer combinations can amplify TIR sequences in one species and non-TIR sequences in a different species.

These results are not surprising, because both TIR and non-TIR genes contain conserved sequences at the P-loop and GLPL motifs. For example, one set of primers from 68 known to amplify TIR type sequences in this species only identified non-TIR

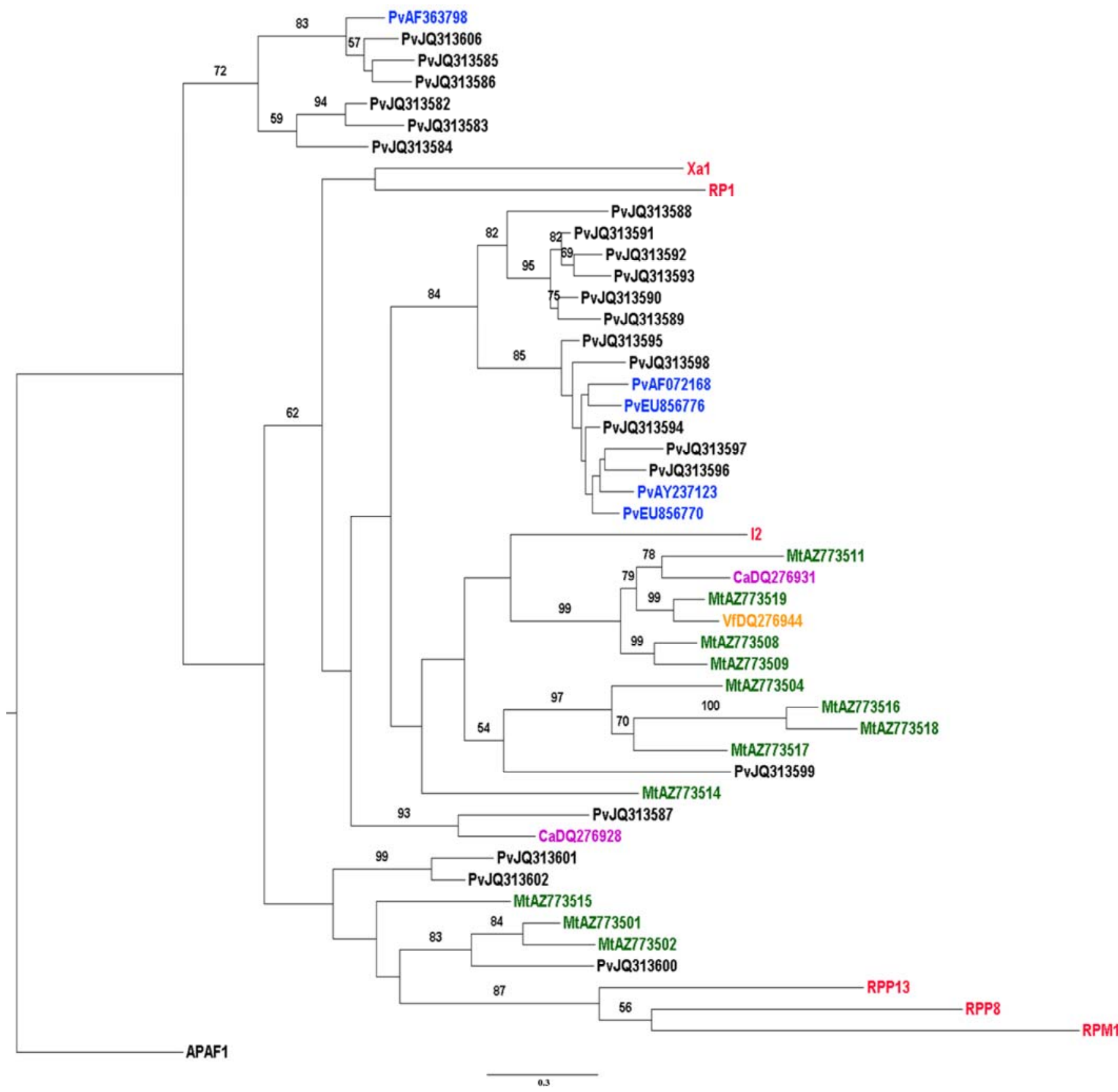



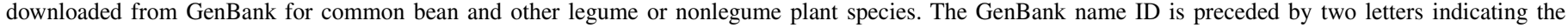

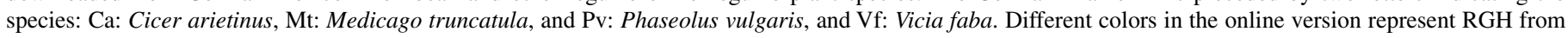
different species with species abbreviation given at the beginning of the gene family name. 


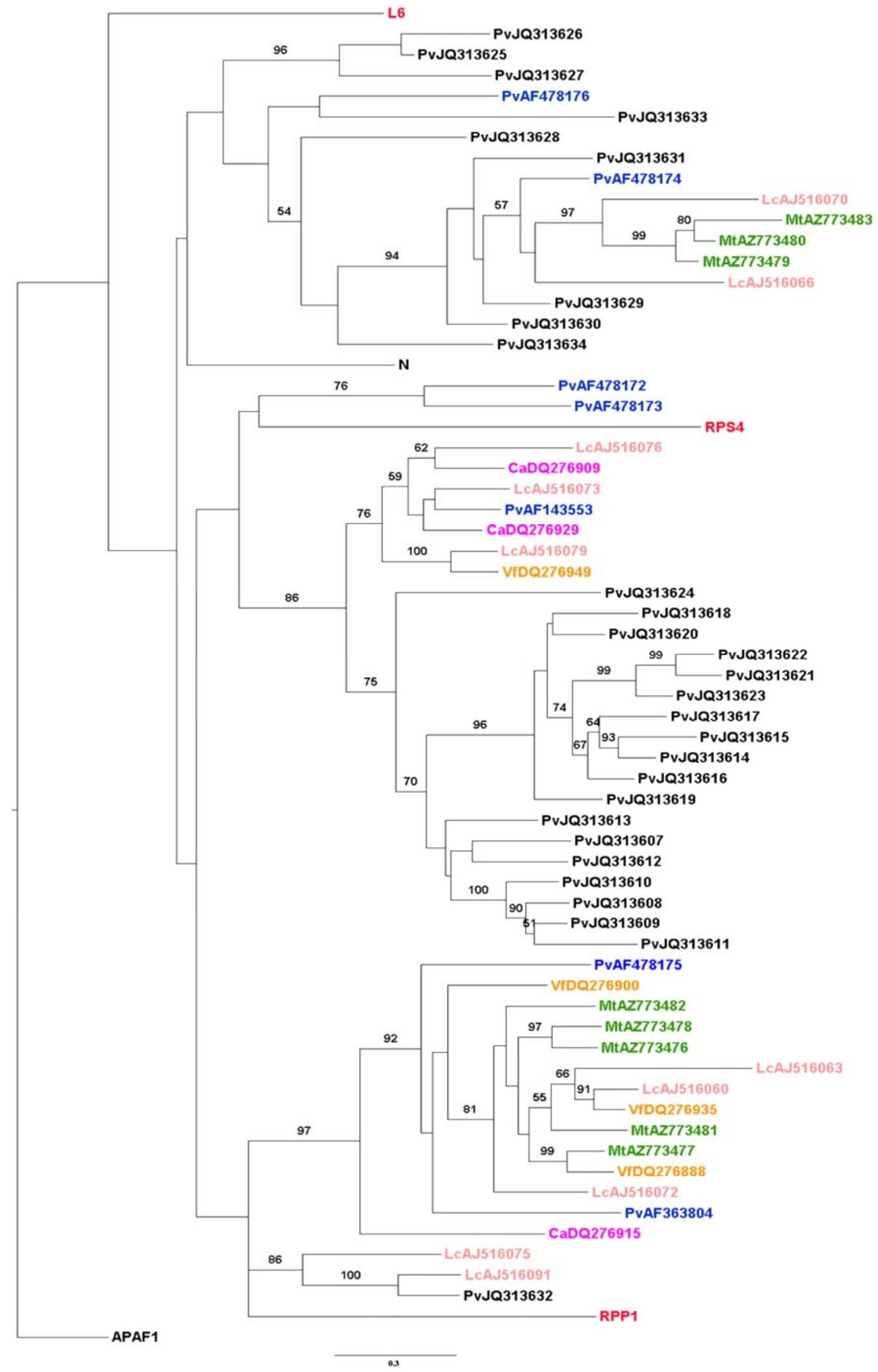

Fig. 4. Phylogenetic relationships between the newly obtained common bean resistance gene homologue (RGH) sequences and previous TIR RGH sequences downloaded from GenBank for common bean and other legume or nonlegume plant species. The GenBank name ID is preceded by two letters indicating the species: Ca: Cicer arietinus, Lc: Lens culinaris, Mt: Medicago truncatula, Pv: Phaseolus vulgaris, and Vf: Vicia faba. Different colors in the online version represent RGH from different species with species abbreviation given at the beginning of the gene family name. 
sequences when used heterologously in Brassica oleracea (28). Studies in Arachis and soybean (Glycine max L.) have found that primers derived from P-loop and GLPL motifs appear to preferentially amplify TIR type genes rather than non-TIR type genes $(6,53,68)$. Similarly, an association between the primer combination and the type of amplified sequence has been suggested in lentil (66). Meanwhile for a monocotyledonous plant, Zingiber, primers that previously amplified TIR and non-TIR sequences only obtained non-TIR NBS-LRR sequences (52).

Primer design is considered another factor which determines the success in amplification of the target products especially in the case of variable RGH sequence. The primer length, the nucleotide composition, and the position and number of degeneracy nucleotide within each primer as well as the prevalence of putative targets in the analyzed genomes analyzed are factors that determined the amount of RGH amplification $(3,44)$. In this study, an important experimental strategy for increasing the number of common bean RGH sequences was the low level of degeneracy in most of the primer combinations, as was recommended by previous results (62).

The NBS-LRR class of resistance genes has been shown to be a very large and variable gene family among plant species. For example in A. thaliana (145 Mbp/1C [megabase pairs per genome]), approximately 200 genes encoding NBS related motifs are estimated to occur in the genome (40). Other plant species with more complex or larger genomes correspondingly can have more NBS-LRR genes. For example, Samuelian et al. (58), predicted 386 NBS encoding genes in their study of red raspberry (Rubus spp., $280 \mathrm{Mbp} / 1 \mathrm{C}$ ); however, they only identified 75 genomic fragments with intermediate similarity to actual NBSLRR genes. Successful RGH cloning is a question of targeting several hundred genes at once.

Based on calculations with Arabidopsis, common bean with a genome size of 450 to $650 \mathrm{Mbp} / 1 \mathrm{C}$ should have up to $850 \mathrm{NBS}$ encoding genes. However, in this study we only obtained 403 RGH sequences and if we include 67 other independent previously cloned NBS-LRR sequences the number of 470 RGH would still be below that expected amount. However, Arabidopsis, due to recent duplication events in the genome, may have an excess of RGH sequences. A recent study of bioinformatically predicted RGH genes in common bean (36) found a total of 365 RGL genes possibly confirming that this legume species has fewer $R$-genes than Arabidopsis. The simple diploid nature of common bean relative to polyploidization events in Arabidopsis may explain this difference.

Some examples that show the difference among the number of RGHs in different fully sequenced plant genomes are as follows: Populus tricocarpa $(550 \mathrm{Mb})$ with $400 \mathrm{RGH}$ genes, $M$. truncatula $(500 \mathrm{Mb})$ with 400 , and Oryza sativa $(430 \mathrm{Mb})$ with 600 (29, $41,45)$. These results could indicate that the number of RGHs is not proportional with the genome size. In some species the RGH number can be either lower or higher than expected. As a result, an in-depth study will need to be conducted with the whole genome sequence of G19833 to determine if our cloning efforts obtained almost the complete set of RGH genes found in common bean.

Apart from the number of RGH genes found in a given species, the ratio of the TIR and non-TIR type sequences has been variable among different plants. In Arabidopsis the ratio has been 2:1 (41), in peanut it was 3:1 (54), and in hop (Humulus lupus L.) this ratio was 1:2 (30). The difference is especially notable when comparing monocotyledoneous versus dicotyledoneous plant genomes, because in dicot species TIR sequences are common but in monocots they are almost completely missing $(44,50)$. This has been observed in a wild relative of potato, Solanum bulbocastanum, where TIR sequences were preferentially amplified (53). In general, non-TIR sequences are more common and heterogeneous than TIR sequences (44); however, our phylogenetic analysis for common bean revealed an almost equal number of clades in the TIR and non-TIR subfamilies of common bean RGH genes at the $90 \%$ identity levels and $25 \%$ more TIR clades at the $80 \%$ identity level. This may be a pattern found in other legumes while in nonlegumes such as pear (Pyrus spp.), 93 TIR resistance gene families and only 5 non-TIR types were identified (69). When using $80 \%$ identity as a threshold to identify RGH families in Solanaceae species, Quirin et al. (53) found about 30\% more nonTIR than TIR gene families. These results suggest that the proportion of TIR gene families is species- and perhaps genus-specific as a consequence of evolutionary processes such as gene-for-gene interaction with avirulence factors from specific plant pathogens.

For common bean, we found a large number of clades corresponding to different RGH families in the phylogenetic tree, which reflects a high polymorphism of these genes in this species. Point mutations and insertion or deletion mutations within the conserved motifs could be the cause of such sequence differentiation and creation of clades of homologous sequences. This diversity could be the adaptive response to the many different pathogens attacking common bean.

While repeated sequences were not taken into account for the phylogenetic analysis we performed, given that they can create confusion in the construction of gene trees and increase the time of analysis (26), similar sequences near 90\% homology were included as individual RGH genes in part of our analysis. Sequences sharing more than $99 \%$ nucleotide identity were not include in the phylogenetic analysis but could be interesting for further study as members of the same families or paralogous genes that have new specificities in resistance (14). The most closely related sequences could be the result of recent duplication events from a common ancestral gene (59).

Grouping of common bean sequences according to their gene pool origins was not evident. However, the fact that some RGHs from the same gene pool grouped together could show that these sequences share conserved motifs inside the NBS domain or have other distinguishable characteristics, specifically in the sequences between the conserved motifs. These specificities could be the result of the differentiation in the evolution of RGH genes in each gene pool. Further sequencing of RGH genes from different bean genotypes might allow us to make more definitive conclusions on Andean versus Mesoamerican resistance genes. The TIR gene family of common bean seems to be extensive as the disease resistance genes RPS4, RPP1, L6, and N were distributed in different clades of the TIR subfamily. The other genes from Arabidopsis, tomato, rice, and corn belonging to non-TIR clades supported the division and classification of common bean RGH genes as non-TIR sequences.

Our results showed that not all common bean RGHs contained a complete ORF. Out of 403 sequences, one fourth exhibited stop codons or frame shift mutations, hence these sequences could be pseudogenes or partial sequences. Pseudogene identification in RGH studies has been important for various plant species. For example in the genus Musa, $25 \%$ of RGH sequences were pseudogenes (3). Dicotyledonous genomes contain a variable number of pseudogenes, ranging from $10 \%$ in tomato, Solanum lycopersicum L. (49), to 50\% in Zingiber spp. (47) and Pinus montícola (34). Pseudogenes could be the result of high rates of recombination, point mutations and indels in RGH sequences as well as rearrangements by transposon that are often observed in $R$-gene families. All of this could be due to the rapid evolution of $R$-genes based on their tandem arrangement in certain parts of the genome $(15,32,67)$. Pseudogenes might drive further evolution since they can be sources of sequences for recombination that allow gene conversion with functional $R$-gene paralogs (42). The variability found within the Kinase- 2 motif of the NBS containing genes might also generate functional differences in the proteins these encode. While most TIR type NBS proteins have an aspartic acid (D) at the end of the Kin-2 domain and most non-TIR type NBS 
proteins have a tryptophan residue (W) $(40,49)$, we found additional variability for this amino acid position. These amino acid changes could determine the specificity of effector and NBSLRR protein interactions as was found for chickpea and faba bean RGH sequences studied by Palomino et al. (48). Variability at the Kin-3 motif could also have an important role in changing $R$-gene function (49) especially compared with the putative anthracnose resistance genes identified for both gene pools of common bean by Ferrier-Cana et al. (16).

The ratio between synonymous and nonsynonymous mutations $(\omega=\mathrm{Ka} / \mathrm{Ks}$, sometimes termed $\mathrm{dN} / \mathrm{dS})$ is a good indicator of the type of selection acting on a specific coding region (63). If the ratio is higher than one, the region is under positive selection, but if the ratio is lower than one, then stabilizing selection is acting on the evolution of the sequence. If the ratio is near one, then neutral selection or a combination between positive and stabilizing selection is involved. Given this, the general values obtained for the common bean TIR and non-TIR gene comparisons $(\omega>1)$ reflected purifying selection. This type of selection is not surprising because the NBS domain is an important signaling component in plant defense activation and is highly conserved across different species and genus (56). However, pairwise comparisons inside the clades 11 and 13 showed values higher than $1(\omega<1)$ indicating positive selection. Sequences undergoing positive selection deserve a more detailed analysis because they may encode functional changes that drive evolution of a specific taxonomic lineage. Whole genome sequences for legumes could identify specific regions of the genome that have been strongly affected by selection using a sliding-window calculation of $\mathrm{Ka} / \mathrm{Ks}$ ratio (10).

For previous studies in common bean RGH sequences, diversifying selection was found at the NBS domain of the candidate for I gene BCMV (Bean common mosaic virus) resistance, but not in the TIR domain of the same gene (62). Meanwhile, Ferrier-Cana et al. (16) found diversifying selection in the LRR domains of four linked NBS-LRR genes from common bean having to do with anthracnose resistance. In our study, the number of sequences analyzed was larger, producing more evidence that NBS domains are mainly subject to purifying selection. LRR domains meanwhile tend to be subject to diversifying selection as they directly interact with AVR factors that are constantly changing with pathogen evolution. In Phaseolus vulgaris, a coevolution process has been observed in the interaction with different pathogens such as Colletotrichum lindemuthianum (23), Phaeoisariopsis griseola (25), and Uromyces appendiculatus (59). Therefore, it is important to undertake more detailed studies of NBS genes in common bean, including genotypes from the Andean and Mesoamerican gene pool, in order to establish the role of pathogen pressure on the evolution of NBS disease-resistance genes in this species.

One further challenge will be to identify the role of each RGH gene and clade in specific disease resistances. Common bean is notoriously affected by multiple diseases such as angular leaf spot, anthracnose, Ascochyta blight, BCMV, BGYMV among many others for a total of at least 86 different diseases reported in Phaseolus vulgaris, as a result of infections with a high variety of pathogen species including bacteria, fungi, nematodes, phytoplasmas, and viruses.

The crop is one of the most ancient of the American cultigens and has been continuously exposed to pressure by different microorganism with the need to respond to new pathogen specificities. Plant defense strategies including effector triggered immunity along with several other types of resistance related proteins are important to understand for controlling disease in the crop. The RGH sequences obtained in the present work are a valuable source of molecular markers, which could be used to tag resistance genes of interest and then transfer them between genotypes by marker assisted selection. This would facilitate the generation of new breeding varieties and contribute to common bean improvement.

The relatively small size of the common bean genome and its low physical to genetic map distance makes this crop species a good candidate for the isolation of $R$-genes via candidate gene techniques. The further exploration of RGH genes in common beans could be used to identify resistance genes in noncommercial genotypes, which may be introgressed into modern varieties through marker assisted selection. This is important in cases such as breeding for anthracnose resistance, where sources of resistance are known but some genes are uncharacterized or for Ascochyta blight resistance, where there are a limited number of sources of resistance in the primary gene pool and only secondary gene pool species are candidates for breeding to improve resistance. The spectrum of resistance offered by RGH sequences is wide across many species of plants and includes resistance to biotrophic or hemibiotrophic pathogens. Thus, there are many opportunities to use the strategy of RGH selection and association with $R$-genes in common bean.

\section{ACKNOWLEDGMENTS}

We are grateful to our funding agencies; Colciencias (Colombia) grant no. 110190520215 (contract 411-07) for fellowship and travel funds, and to the National Science Foundation (USA) and Generation Challenge Program (CGIAR) for supply funds.

\section{LITERATURE CITED}

1. Aarts, M. G. M., Hekkert, B. L., Holub, E. B., Beynon, J. L., Stiekema, W. J., and Pereira, A. 1998. Identification of R-gene homologous DNA fragments genetically linked to disease resistance loci in Arabidopsis thaliana. Mol. Plant-Microbe Interact. 11:251-258.

2. Ameline-Torregrosa, C., Wang, B. B., O'Bleness, M. S., Deshpande, S., Zhu, H., Roe, B., Young, N. D., and Cannon, S. B. 2008. Identification and characterization of nucleotide-binding site-leucine-rich repeat genes in the model plant Medicago truncatula. Plant Physiol. 146:5-21.

3. Azhar, M., and Heslop-Harrison, J. S. 2008. Genomes, diversity and resistance gene analogues in Musa species. Cytogenet. Genome Res. 121:59-66.

4. Bailey, T. L., and Gribskov, M. 1998. Combining evidence using p-values: Application to sequence homology searches. Bioinformatics 14:48-54.

5. Bassett, M. J. 2004. List of genes-Phaseolus vulgaris. Annu. Rep. Bean Improvement Cooperative-BIC 47:1-5.

6. Bertioli, D., Leal-Bertioli, S., Lion, M., Santos, V., Pappas, G., Cannon, S., and Guimarães, P. 2003. A large scale analysis of resistance gene homologues in Arachis. Mol. Genet. Genomics 270:34-45.

7. Blair, M., Buendía, H., Giraldo, M., Métais, I., and Peltier, D. 2008. Characterization of AT-rich microsatellites in common bean (Phaseolus vulgaris L.). TAG Theor. Appl. Genet. 118:91-103.

8. Broughton, W. J., Hernández, G., Blair, M., Beebe, S., Gepts, P., and Vanderleyden, J. 2003. Beans (Phaseolus spp.)-Model food legumes. Plant Soil 252:55-128.

9. Cannon, S. B., Zhu, H., Baumgarten, A. M., Spangler, R., May, G., and Cook, D. R. 2002. Diversity, distribution, and ancient taxonomic relationships within the TIR and non-TIR NBS-LRR resistance gene subfamilies. J. Mol. Evol. 54:548-562.

10. Choi, S. S., and Lahn, B. T. 2003. Adaptive evolution of MRG, a neuronspecific gene family implicated in nociception. Genome Res. 13:2252-2259.

11. Creusot, F., Macadré, C., Cana, E. F., Riou, C., Geffroy, V., Sévignac, M., Dron, M., and Langin, T. 1999. Cloning and molecular characterization of three members of the NBS-LRR subfamily located in the vicinity of the Co-2 locus for anthracnose resistance in Phaseolus vulgaris. Genome 42:254-264.

12. Dangl, J. L., and Jones, J. D. G. 2001. Plant pathogens and integrated defence responses to infection. Nature (London) 411:826-833.

13. Dellaporta, S., Wood, J., and Hicks, J. 1983. A plant DNA minipreparation: Version II. Plant Mol. Biol. Rep. 1:19-21.

14. Dodds, P. N., Lawrence, G. J., and Ellis, J. G. 2001. Six amino acid changes confined to the leucine-rich repeat $\beta$-strand/ $\beta$-turn motif determine the difference between the $\mathrm{P}$ and $\mathrm{P} 2$ rust resistance specificities in flax. Plant Cell 13:163-178.

15. Ellis, J., and Jones, D. 1998. Structure and function of proteins controlling strain-specific pathogen resistance in plants. Curr. Opin. Plant Biol. 1:288-293. 
16. Ferrier-Cana, E., Geffroy, V., Macadré, C., Creusot, F., Imbert-Bolloré, P., Sévignac, M., and Langin, T. 2003. Characterization of expressed NBSLRR resistance gene candidates from common bean. Theor. Appl. Genet. 106:251-261

17. Ferrier-Cana, E., Macadré, C., Sévignac, M., David, P., Langin, T., and Geffroy, V. 2005. Distinct post-transcriptional modifications result into seven alternative transcripts of the CC-NBS-LRR gene JA1tr of Phaseolus vulgaris. TAG Theor. Appl. Genet. 110:895-905.

18. Flor, H. H. 1971. Current status of the gene-for-gene concept. Annu. Rev. Phytopathol. 9:275-296.

19. Galeano, C., Fernandez, A., Franco-Herrera, N., Cichy, K., McClean, Vanderleyden, and Blair, M. 2011. Saturation of an intra-gene pool linkage map: Towards a unified consensus linkage map for fine mapping and synteny analysis in common bean. PLoS ONE 6:e28135.

20. Galeano, C., Fernandez, A., Gomez, M., and Blair, M. 2009. Single strand conformation polymorphism based SNP and indel markers for genetic mapping and synteny analysis of common bean (Phaseolus vulgaris L.). BMC Genomics 10:629.

21. Geffroy, V., Creusot, F., Falquet, J., Sévignac, M., Adam-Blondon, A. F., Bannerot, H., Gepts, P., and Dron, M. 1998. A family of LRR sequences in the vicinity of the Co-2 locus for anthracnose resistance in Phaseolus vulgaris and its potential use in marker-assisted selection. Theor. Appl. Genet. 96:494-502.

22. Geffroy, V., Macadré, C., David, P., Pedrosa-Harand, A., Sévignac, M., Dauga, C., and Langin, T. 2009. Molecular analysis of a large subtelomeric nucleotide-binding-site-leucine-rich-repeat family in two representative genotypes of the major gene pools of Phaseolus vulgaris. Genetics 181:405-419.

23. Geffroy, V., Sicard, D., de Oliveira, J. C. F., Sévignac, M., Cohen, S., Gepts, P., Neema, C., Langin, T., and Dron, M. 1999. Identification of an ancestral resistance gene cluster involved in the coevolution process between Phaseolus vulgaris and its fungal pathogen Colletotrichum lindemuthianum. Mol. Plant-Microbe Interact. 12:774-784.

24. Gepts, P., Aragão, F. J. L., Barros, E., Blair, M. W., Brondani, R., Broughton, W., Galasso, I., Hernández, G., Kami, J., Lariguet, P., McClean, P., Melotto, M., Miklas, P., Pauls, P., Pedrosa-Harand, A., Porch, T., Sánchez, F., Sparvoli, F., and KangFu, Y. 2008. Genomics of Phaseolus beans, a major source of dietary protein and micronutrients in the tropics. Pages 113-143 in: Plant Genetics and Genomics: Crops and Models, Volume 1. Springer-Verlag GmbH, Heidelberg, Germany.

25. Guzman, O., Gilbertson, R. L., Nodari, R., Johnson, W. C., Temple, D., Mandala, D., Mkandawiew, A. B. C., and Gepts, P. 1995. Characterization of variability in the fungus Phaeoisariopsis griseola suggests coevolution with the common bean (Phaseolus vulgaris). Phytopathology 85:600-607.

26. Hall, B. 2008. Phylogenetic Trees Made Easy. 3rd ed. Sinauer Associates, Inc., Sunderland, MA.

27. Hanai, L. R., Santini, L., Camargo, L. E. A., Fungaro, M. H. P., Gepts, P., Tsai, S. M. 2010. Extension of the core map of common bean with ESTSSR, RGA, AFLP, and putative functional markers. Mol. Breed. 25:25-45.

28. Kanazin, V., Marek, L. F., and Shoemaker, R. C. 1996. Resistance gene analogs are conserved and clustered in soybean. Proc. Nat. Acad. Sci. USA 93:11746-11750.

29. Kohler, A., Rinaldi, C., Duplessis, S., Baucher, M., Geelen, D., Duchaussoy, F., Meyers, B., Boerjan, W., and Martin, F. 2008. Genomewide identification of NBS resistance genes in Populus trichocarpa. Plant Mol. Biol. 66:619-636.

30. Kozjak, P., Jakše, J., and Javornik, B. 2009. Isolation and sequence analysis of NBS-LRR disease resistance gene analogs from hop Humulus lupulus L. Plant Sci. 176:775-782.

31. Leister, D., Ballvora, A., Salamini, F., and Gebhardt, C. 1996. A PCR based approach for isolating pathogen resistance genes from potato with potential for wide application in plants. Nat. Genet. 14:421-429.

32. Leister, D., Kurth, J., Laurie, D. A., Yano, M., Sasaki, T., and Devos, K. 1998. Rapid reorganization of resistance gene homologues in cereal genomes. Proc. Nat. Acad. Sci. USA 95:370-375.

33. Librado, P., and Rozas, J. 2009. DnaSP v5: A software for comprehensive analysis of DNA polymorphism data. Bioinformatics 25:1451-1452.

34. Liu, J. J., and Ekramoddoullah, A. K. M. 2003. Isolation, genetic variation and expression of TIR-NBS-LRR resistance gene analogs from western white pine (Pinus monticola Dougl. ex. D. Don.). Mol. Genet. Genomics 270:432-441

35. Liu, J. J., Liu, X., Dai, L., and Wang, G. 2007. Recent progress in elucidating the structure, function and evolution of disease resistance genes in plants. J. Genet. Genomics 34:765-776.

36. Liu, Z., Crampton, M., Todd, A., and Kalavacharla, V. 2012. Identification of expressed resistance gene-like sequences by data mining in 454derived transcriptomic sequences of common bean (Phaseolus vulgaris L.). BMC Plant Biol. 12:42.

37. López, C. E., Acosta, I. F., Jara, C., Pedraza, F., Gaitán-Solís, E., Gallego, G., Beebe, S., and Tohme, J. 2003. Identifying resistance gene analogs associated with resistances to different pathogens in common bean. Phytopathology 93:88-95.

38. McClean, P. E., Lavin, M., Gepts, P., and Jackson, S. A. 2008. Phaseolus vulgaris: A diploid model for soybean. Pages 55-76 in: Plant Genetics and Genomics: Crops and Models, Volume 2. Springer-Verlag GmbH, Heidelberg, Germany.

39. McIntyre, C. L., Casu, R. E., Drenth, J., Knight, D., Whan, V. A., Croft, B. J., Jordan, D. R., and Manners, J. M. 2005. Resistance gene analogues in sugarcane and sorghum and their association with quantitative trait loci for rust resistance. Genome 48:391-400.

40. Meyers, B. C., Dickerman, A. W., Michelmore, R. W., Subramoniam, S., Sobral, B. W., and Young, N. D. 1999. Plant disease resistance genes encode members of an ancient and diverse protein family within the nucleotide-binding superfamily. Plant J. 20:317-332.

41. Meyers, B. C., Kozik, A., Griego, A., Kuang, H. H., and Michelmore, R. W. 2003. Genome-wide analysis of NBS-LRR-encoding genes in Arabidopsis. Plant Cell 15:809-834.

42. Michelmore, R. W., and Meyers, B. C. 1998. Clusters of resistance genes in plants evolve by divergent selection and a birth-and-death process. Genome Res. 8:1113-1130.

43. Miklas, P. N., Kelly, J. D., Beebe, S. D., and Blair, M. W. 2006. Common bean breeding for resistance against biotic and abiotic stresses: From classical to MAS breeding. Euphytica 147:105-131.

44. Miller, R. N. G., Bertioli, D. J.,Baurens, F. C., Santos, C. M. R., Alves, P. C., Martins, N. F., Togawa, R. C., Souza Júnior, M. T., and Pappas Júnior, G. J. 2008. Analysis of non-TIR NBS-LRR resistance gene analogs in Musa acuminata Colla: Isolation, RFLP marker development, and physical mapping. BMC Plant Biol. 8.

45. Monosi, B., Wisser, R. J., Pennill, L., and Hulbert, S. H. 2004. Fullgenome analysis of resistance gene homologues in rice. Theor. Appl. Genet. 109:1434-1447.

46. Mutlu, N., Miklas, P., and Coyne, D. 2006. Resistance gene analog polymorphism (RGAP) markers co-localize with disease resistance genes and QTL in common bean. Mol. Breed. 17:127-135.

47. Nair, R. A., and Thomas, G. 2007. Isolation, characterization and expression studies of resistance gene candidates (RGCs) from Zingiber spp. TAG Theor. Appl. Genet. 116:123-134.

48. Palomino, C., Satovic, Z., Cubero, J. I., and Torres, A. M. 2006. Identification and characterization of NBS-LRR class resistance gene analogs in faba bean (Vicia faba L.) and chickpea (Cicer arietinum L.). Genome 49:1227-1237.

49. Pan, Q., Liu, Y.-S., Budai-Hadrian, O., Sela, M., Carmel-Goren, L., and Zamir, D. 2000. Comparative genetics of nucleotide binding site-leucine rich repeat resistance gene homologues in the genomes of two dicotyledons: Tomato and Arabidopsis. Genetics 155:309-322.

50. Pan, Q. L., Wendel, J., and Fluhr, R. 2000. Divergent evolution of plant NBS-LRR resistance gene homologues in dicot and cereal genomes. J. Mol. Evol. 50:203-213.

51. Peñuela, S., Danesh, D., and Young, N. D. 2002. Targeted isolation, sequence analysis, and physical mapping of nonTIR NBS-LRR genes in soybean. Theor. Appl. Genet. 104:261-272.

52. Priya, R. S., and Subramanian, R. B. 2008. Isolation and molecular analysis of R-gene in resistant Zingiber officinale (ginger) varieties against Fusarium oxysporum f. sp. zingiberi. Special Section: Exploring horizons in biotechnology: A global venture. Bioresource Technol. 99:4540-4543

53. Quirin, E. A., Mann, H., Meyere, R. S., Triani, A., Chiusano, Litt, M. L. A., and Bradeen, J. M. 2012. Evolutionary meta-analysis of solanaceous resistance gene and solanum resistance gene analog sequences and a practical framework for cross-species comparisons. Mol. Plant-Microbe Interact. 25:603-612

54. Radwan, O. E., Ahmed, T. A., and Knapp, S. J. 2010. Phylogenetic analyses of peanut resistance gene candidates and screening of different genotypes for polymorphic markers. Saudi J. Biol. Sci. 17:43-49.

55. Ramírez, M., Graham, M. A., Blanco-López, L., Silvente, S., MedranoSoto, A., Blair, M. W., Hernández, G., Vance, C. P., and Lara, M. 2005. Sequencing and analysis of common bean ESTs. Building a foundation for functional genomics. Plant Physiol. 137:1211-1227.

56. Reddy, I. N. B. L., Reddy, D. S., Narasu, M. L., and Sivaramakrishnan, S 2011. Characterization of disease resistance gene homologues isolated from finger millet (Eleusine coracana L. Gaertn). Mol. Breed. 27:315328.

57. Rivkin, M. I., Vallejos, C. E., and McClean, P. E. 1999. Disease-resistance related sequences in common bean. Genome 42:41-47.

58. Samuelian, S. K., Baldo, A. M., Pattison, J. A., and Weber, C. A. 2008. Isolation and linkage mapping of NBS-LRR resistance gene analogs in red raspberry (Rubusidaeus L.) and classification among 270 Rosaceae NBS-LRR genes. Tree Genet. Genomes 4:881-896.

59. Sandlin, C. M., Steadman, J. R., Araya, C. M., and Coyne, D. P. 1999. Isolates of Uromyces appendiculatus with specific virulence to landraces 
of Phaseolus vulgaris of Andean origin. Plant Dis. 83:108-113.

60. Schlueter, J. A., Goicoechea, J. L., Collura, K., Gill, N., Lin, J. Y., Yu, Y. S., Kudrna, D., Zuccolo, A., Vallejos, C. E., Muñoz-Torres, M., Blair, M. W., Tohme, J., Tomkins, J., McClean, P., Wing, R. A., and Jackson, S. A. 2008. BAC-end sequence analysis and a draft physical map of the common bean (Phaseolus vulgaris L.) genome. Trop. Plant Biol. 1:40-48.

61. Schwartz, H. F., Steadman, J. R., Hall, R., and Forster, R. L. 2005. Compendium of Bean Diseases. American Phytopathological Society, St. Paul, MN.

62. Shen, K. A., Meyers, B. C., Islam-Faridi, M. N., Chin, D. B., Stelly, D. M., and Michelmore, R. W. 1998. Resistance gene candidates identified by PCR with degenerate oligonucleotide primers map to clusters of resistance genes in lettuce. Mol. Plant-Microbe Interact. 11:815-823.

63. Vallejos, C. E., Astua-Monge, G., Jones, V., Plyler, T. R., Sakiyama, N. S., and Mackenzie, S. A. 2006. Genetic and molecular characterization of the I locus of Phaseolus vulgaris. Genetics 172:1229-1242.

64. Vallejos, C. E., Sakiyama, N. S., and Chase, C. D. 1992. A molecular marker-based linkage map of Phaseolus vulgaris L. Genetics 131:733740 .

65. Xu, X., Kawasaki, S., Fujimura, T., and Wang, C. T. 2005. A protocol for high-throughput extraction of DNA from rice leaves. Plant Mol. Biol. Rep. 23:291-295.

66. Yaish, M. W. F., Sáenz de Miera, L. E., and Pérez de la Vega, M. 2004. Isolation of a family of resistance gene analogue sequences of the nucleotide binding site (NBS) type from Lens species. Genome 47:650-659.

67. Young, N. D. 2000. The genetic architecture of resistance. Curr. Opin. Plant Biol. 3:285-290.

68. Yu, Y. G., Buss, G. R., and Saghai Maroof, M. A. 1996. Isolation of a superfamily of candidate disease-resistance genes in soybean based on a conserved nucleotide-binding site. Proc. Natl. Acad. Sci. USA 93:1175111756.

69. Zhang, H. L., Wang, Y. J., Zhang, C. H., Wang, X. P., Li, H., and Xu,W. R. 2011. Isolation, characterization and expression analysis of resistance gene candidates in pear (Pyrus spp.). Sci. Hort. 127:282-289. 